\title{
A Review of Electromagnetic Activity in Cellular Mechanics
}

\author{
Ronald L. Huston \\ Department of Mechanical and Materials Engineering, University of Cincinnati, Cincinnati, USA \\ Email: ron.huston@uc.edu
}

How to cite this paper: Huston, R.L. (2016) A Review of Electromagnetic Activity in Cellular Mechanics. Advances in Bioscience and Biotechnology, 7, 360-371. http://dx.doi.org/10.4236/abb.2016.79035

Received: August 15, 2016

Accepted: September 10, 2016

Published: September 13, 2016

Copyright $\odot 2016$ by author and Scientific Research Publishing Inc. This work is licensed under the Creative Commons Attribution International License (CC BY 4.0).

http://creativecommons.org/licenses/by/4.0/ (c) (i) Open Access

\begin{abstract}
This is a review of recent literature concerning electromagnetic effects on cellular mechanics. "Recent" refers primarily to papers published in this (the $21^{\text {st }}$ ) century. The review shows that there are relatively few papers on cellular electromagnetics as compared with those on proteins, biochemistry, and cellular anatomy. The principal finding of the reviewed papers is that cellular electromagnetic fields appear to arise from longitudinal vibrations of the filaments making up the walls of the microtubules. Microtubules are long hollow cylinders which form the overall structure of the centrioles. The microtubules, and therefore the centrioles themselves, are arranged in nine sets of parallel blades with each blade having three microtubules. The centrioles occur in pairs perpendicularly to each other. During mitosis (cell division) the centriole pair becomes two pair which then separate and divide the cell into two. It seems that electromagnetic forces play a central role in this division. Electromagnetic activity in wound healing and in the imaging and treatment of tumors is discussed.
\end{abstract}

\section{Keywords}

Centrioles, Microtubules, Cellular Electromagnetism, Cancer

\section{Introduction}

This is the third in a series of review papers on centriolar cellular mechanics with the focus here being on electromagnetic effects. The first two papers reviewed: 1) the literature on centrioles in general and then 2) the centriolar microtubules-the principal structural components of the centrioles [1] [2].

The research and findings cited herein, and in the two earlier papers, are primarily those documented to date in this, the $21^{\text {st }}$ century. As with many reviews, important writings are either inadvertently omitted or are not given the attention they deserve. I sincerely regret such omissions and/or under-emphases. 
The implication of the title is that electromagnetic effects are not only important but also essential in cellular mechanics. Unfortunately, however, the electromagnetic effects are often omitted, or not discussed in depth, in biology papers and books. But upon a close examination of intracellular mechanics, and in particular with the centrioles, the presence of electromagnetic forces is evident. Perhaps the most persuasive evidence is the observed forces exerted at a distance during centriole pair separation and during mitosis via the kinetochores [3]-[6].

Also, it has long been known that there is a voltage change across different sides of an open wound [7] [8].

How do these electromagnetic fields and their associated forces arise? There is now considerable agreement among researchers that vibrations of filaments of the microtubules (MT filaments) establish oscillating magnetic and electric fields.

As noted above, the microtubules form the structure of the centrioles: specifically, each centriole consists of nine "blades" of microtubule triplets (thus a total of $27 \mathrm{mi}$ crotubules per centriole). The microtubules themselves are hollow cylinders whose walls are composed of 13 longitudinal filaments. The filaments are strings of $\alpha / \beta$ tubulin dimers connected end-to-end.

Figures 1-4 provide sketches of the structures of the centrioles, the microtubules, and the $\alpha / \beta$ dimers.

The $\alpha / \beta$ tubulin dimers have positive and negative charges at their ends. Thus when they are stacked together end-to-end in a microtubule filament, they are analogous to a series of batteries connected end-to-end, as in a long flashlight. During filament movement via their vibration oscillation these charged dimers produce an electromagnetic field [9]-[12].

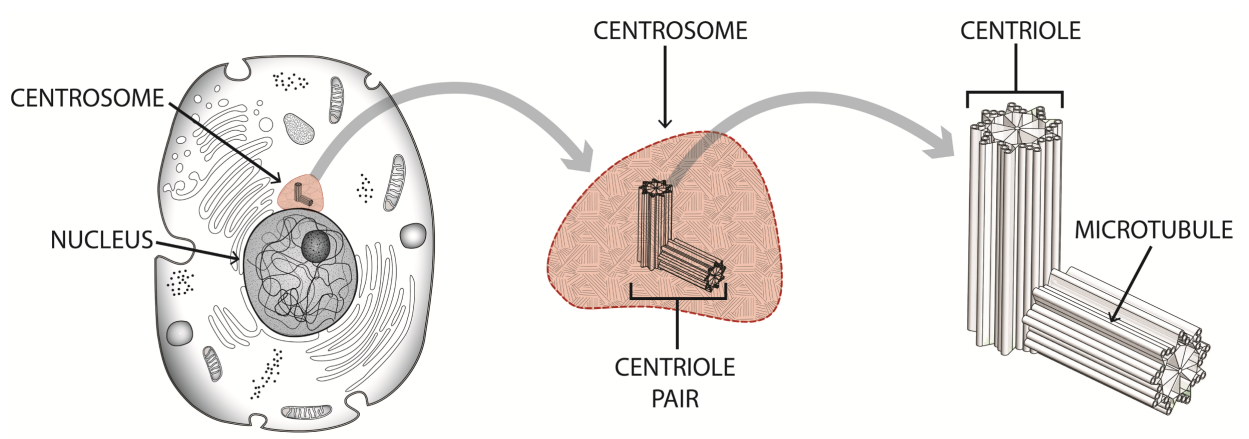

Figure 1. The structures of the centrioles.

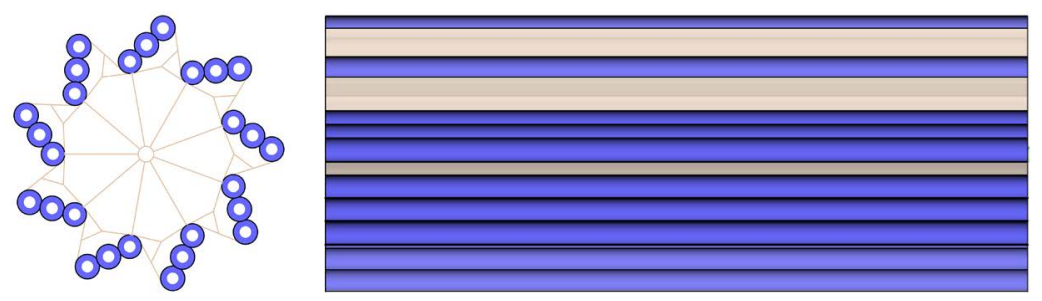

Figure 2. The structures ofthe microtubules. 


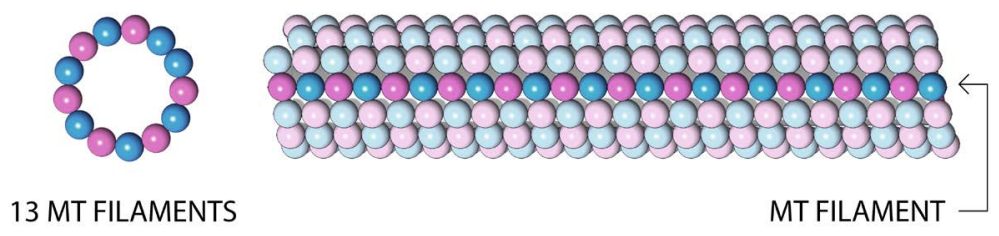

Figure 3. The structures of MT filaments.

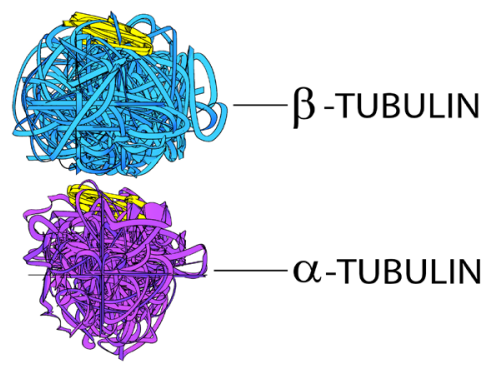

Figure 4. The structures of the $\alpha / \beta$ dimers.

The balance of the paper is divided into four sections with the first of these providing a background review for the sequel. The next two sections present evidences of electromagnetic effects and their magnitudes. The paper concludes with a brief discussion and envisions of applications of the findings.

\section{Preliminary Considerations: Review of Centriole Duplication and Microtubule Development}

The centrioles form a pair of perpendicular cylinders lying adjacent to the nucleus in all eukaryotic (human and animal) cells. The centrioles are hollow cylinders approximately 400 to $500 \mathrm{~nm}$ in length and $200 \mathrm{~nm}$ in diameter. Structurally they consist of nine blades of triplets of microtubules-themselves hollow cylinders approximately $25 \mathrm{~nm}$ in outer diameter and $15 \mathrm{~nm}$ inner diameter.

Of all the organelles and organs of the body the centrioles are unique in that they have straight-line geometries and no membrane cover. Also, their perpendicularity to each other is maintained since one of the pair (the "daughter") grows from the surface of the base of the other (the "mother"). The axis of the daughter thus intersects the axis of the mother at a right angle.

Although the details of centriole duplication and development are still under investigation, the generally accepted process is as follows [3]-[6]: During an intermediate time in the cell cycle ("interphase")—-specifically, the "S-phase," a protein known as "asterless" attaches itself to one of the outside microtubules at the base of the about-tobecome mother centriole. The asterless then recruits protein Plk4 ("polo-like kinase four") to form a base and govern the construction of a new centriole [85]. Plk4 is also known as (aka) "SAK".

Plk4 then distributes itself like a patch or base at the lower end of the mother centriole. Next with the aid of another protein STIL (aka "SIL") the Plk4 and SIL recruit yet another protein SAS6 atop the Plk4 patch. 
At this point, the SAS6 expands symmetrically by developing nine spokes growing away from its center. The outer ends of these spokes form the seats of the microtubules with each spoke supporting three microtubules.

The microtubule bases and the microtubules themselves are composed of tubulin proteins: The bases consist of rings of gamma tubulin. These however are not flat (or planar) but instead their ends overlap so that they have the appearance of a lock washer [13]. Also, the rings are not uniform along their circumference but instead there are 13 equally spaced pores (or channels) through which the $\alpha / \beta$ tubulin dimers pass to form the filaments making up the walls of the microtubulin.

Surrounding the centrioles is a pool of as many as 100 proteins, an abundance of which are the $\alpha / \beta$, and $\gamma$ tubulins. This protein pool is known as the "centrosome" and also as the "microtubule organizing center" or MTOC.

The MTOC is believed to be "electron dense" [14]-[16] and thus the base of the centrioles is negatively charged and the distal ends are then positive.

\section{Evidence of Electromagnetic Effects}

As noted earlier there is a charge difference between either side of an open wound. This has long been known: It was discovered as early as 1860 by duBois-Raymond [7].

More recently in the 1960s and 1970s, Paul Schafer, while studying esophageal cancer cells, discovered disruptions in centriole geometries and also that similar centriolar geometric disruptions could be caused by strong electromagnetic fields [14]-[17]. Correspondingly, in 2008 and 2013 Pokorný, et al. reported that electromagnetic fields can cause cancer [18] [19].

In 1990 Weiss, et al. reported that animals with amputated limbs have a strong negative polarity on the stump [8].

The interest in electromagnetic fields both within biosystems and the effects of electromagnetic fields on biosystems greatly increased at about the turn of this the $21^{\text {st }}$ century. Many investigators have identified the source of cellular electromagnetic fields as due to longitudinal vibration of microtubular filaments (e.g. [9] [12] [20]-[27]).

The most impressive evidence of cellular electromagnetic activity occurs during mitosis: First as a centriole pair is duplicated, the resulting two pairs push against each other and separate. Next, as the centriole pairs are pushed apart, the newest (or youngest) of the two pairs is driven around the nucleus to the diametrically opposite side, while the older of the centriole pair remains in place. Finally, the oppositely positioned centrioles send forth microtubules toward each other about the surface of the nucleus, thus making up the "mitotic spindle". At the same time the membrane of the nucleus between the opposing centriole pairs begins to soften and shrink. Microtubules emerging from the kinetochores, within the nucleus, extend and join the microtubules of the mitotic spindle and in this way separate the cell into two cells.

Figure 5 provides a representation of this event.

In elementary mechanics a "force" is often defined as a "push or a pull" [28]. In the foregoing description of mitosis, there is evidence of both pushing and pulling-and 


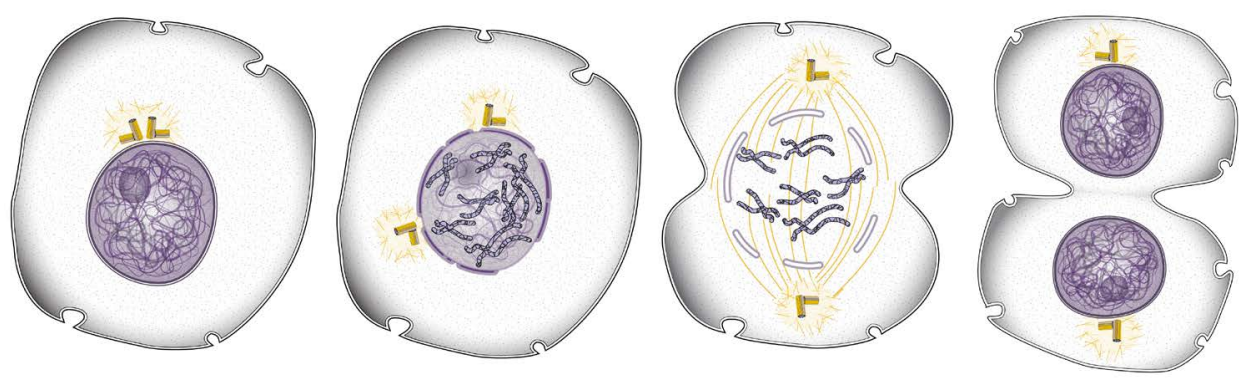

Figure 5. A representation of cell separation (mitosis).

also at a distance. Aside from gravity, only electromagnetism exerts forces at a distance.

Tumors composed of cancer cells provide additional expressive evidence of electromagnetic cellular activity. For example, breast cancer tumors produce a charge that can be measured externally [29] [30]. Correspondingly there is a voltage gradient between cancer tissue in tumors and neighboring normal tissue [31]-[34].

It is believed that the enhanced electromagnetic fields of cancerous tumors attract blood vessels which then expand and also become malignant [35].

Cancer cells are known to have supernumerary centrioles [26] [36]-[70]. These centrioles tend to cluster together [71] and these clusters are believed to be the source of the enhanced electromagnetic fields associated with cancerous tissue.

Other evidence of cellular electromagnetic effects is the aligning of chromosomes along the axis of the electric field [11], and as noted earlier, electromagnetic fields enhance blood vessel growth [35] [72].

Finally, some have suggested that the vibrating filaments within the microtubules are ferromagnetic [73]-[75].

\section{Experimental Findings and Data}

Unfortunately, due to the minute size of cellular tissue, there is a paucity of available recorded data about the magnitudes of cellular electromagnetics. However, improvements in microscopy and measurement techniques are likely to produce new findings in both the geometrical and physical characteristics of centrioles and their microtubules.

Here are some approximate data:

First, for wounds: in 2004 Zhao, et al. [30] reported that there is a voltage drop of 40 to 200 millivolts per millimeter ( $\mathrm{mv} / \mathrm{mm}$ ) across open skin wounds. Also in 2004, Mycielska and Djamgoz [76] reported that transepitheliel potentials range from a few millivolts to tens of millivolts.

Next, at the other extreme, in the small, the data is even less precise. For example, Stracke, et al. [77] found the charge on a tubulin dimer to be $0.19 \mathrm{e}$ where e is the charge on an electron $\left(1.6 \times 10^{-19} \mathrm{c}\right)$. Alternatively, other models based upon chrystallographic data predict values 50 times or more as large.

In like manner researchers have measured the tubulin dimer dipole moment (opposite end charges times separation distance) to be approximately 100 Debye [22] [78] 
[79]. (A "Debye" is $10^{-29} \mathrm{~cm}$.) Others have indicated the moment to be as large as 6000 Debye [80].

Although these are small numbers, Pokorný [81] indicates that the electric field near a microtubule can be as large as $10^{8} \mathrm{v} / \mathrm{m}$.

Finally, with electromagnetic fields being created by accelerating charges there is interest in the frequencies of microtubule filament vibration. These numbers range from $\mathrm{kHz}$ to $\mathrm{THz}$ with a typical value of $465 \mathrm{MHz}$ [22] [82] [83].

\section{Discussion and Applications of the Findings}

Of all these findings, that of greatest interest is the role of electromagnetic fields in tumors and in tumorigenesis. As noted earlier tumors (particularly malignant tumors) appear to have greater magnetic fields than normal tissue. This increased field strength with tumors is believed to be due to the magnetic field strengthening by the supernumerary centrioles occurring in cancer cells. The field strengthening is believed to arise due to the resulting large number of vibrating microtubules. Also, as noted earlier, the supernumerary centrioles tend to cluster together [71].

The supernumerary centrioles, the clustering, and the enhanced electromagnetic field of cancer cells thus provide a biomarker for imaging and treatment.

A promising approach currently being pursued by a number of researchers is to use magnetically charged nanoparticles to be attracted by the enhanced magnetic field of the centrioles. The envisioned nanoparticles would be small enough to penetrate the cell membrane and then adhere to the centriole clusters. At this point the nanoparticles could achieve targeted drug delivery to cancer cells; alternatively the nanoparticles could be vibrated externally, also killing the cell via heating; or taken as a group, the nanoparticles could be used to image the tumor for precise surgical or radiation treatment.

There are two principal advantages of using magnetically charged nanoparticles for cancer treatment: First, normal tissue cells, having only a pair of centrioles, and thus a low magnetic field would not attract the charged nanoparticles. Second, the charged nanoparticles could be sufficiently numerous so that all tumor cells could eventually be eliminated.

A difficulty with using magnetically charged nanoparticles however is that they tend to cluster together and thus lose their effectiveness in reaching and penetrating the cancer cells. To overcome this problem, some have suggested using superparametric nanoparticles which can become magnetized in the vicinity of an electromagnetic field [84].

Much remains to be done before these concepts can be developed and tested.

\section{Acknowledgements}

Support for this research was provided by The Schafer Foundation for Centriolar Research and is sincerely appreciated. Also, the support and encouragement of Bardyl Tirana and Roger Adelman is acknowledged and appreciated. Finally, the support of Mary Schartman in preparing the figures is acknowledged. 


\section{References}

[1] Huston, R.L. (2016) A Review of Centriole Activity, and Wrongful Activity, During Cell Division. Advances in Bioscience and Biotechnology, 7, 169-182. http://dx.doi.org/10.4236/abb.2016.73015

[2] Huston, R.L. (2016) Mechanics of Centriole Microtubules. Advances in Biosciences and Biotechnology, 7, 266-277. http://dx.doi.org/10.4236/abb.2016.76025

[3] Alberts, B., Bray, D., Lewis, J., Raff, M., Roberts, K. and Watson, J.D. (1994) Molecular Biology of the Cell, Third Edition, Garland Publishing, New York.

[4] Hardin, J., Bertoni, G., and Kleinsmith, L.J. (2015) Becker's World of the Cell. Eighth Ed., Pearson, San Francisco.

[5] Marieb, E.N. (1991) Human Anatomy and Physiology, Third Edition, Benjamin/Cummings Publishing, Redwood City, CA, Chapter 3, 60-101.

[6] Guest, C. (1996) Biology Smart: The Princeton Review. Random House, New York, 133135.

[7] Cheng, K. and Zou, C. (2006) Physics Models of Centriole Replication. Medical Hypotheses, 67, 572-577. http://dx.doi.org/10.1016/j.mehy.2006.02.041

[8] Weiss, D.S., Kirsner, R. and Eaglstein, W.H. (1990) Electrical Stimulation and Wound Healing. Archives of Dermatology, 126, 222-225. http://dx.doi.org/10.1001/archderm.1990.01670260092018

[9] Pokorný, J. (2011) Electrodynamic Activity of Healthy and Cancer Cells. Journal of Physics. Conference Series, 329, Article ID: 012007. http://dx.doi.org/10.1088/1742-6596/329/1/012007

[10] Zhao, Y. and Zhan, Q. (2012) Electric Fields Generated by Synchronized, Oscillation of Microtubules, Centrosomes and Chromosomes Regulate the Dynamics of Mitosis and Meiosis. Theoretical Biology and Medical Modelling, 9, 26. http://dx.doi.org/10.1186/1742-4682-9-26

[11] Zhao, Y. and Zhan, Q. (2012) Electric Oscillation and Coupling of Chromatin Regulate Chromosome Packaging and Transcription in Eukaryotic Cells. Theoretical Biology and Medical Modelling, 9, 27-38. http://dx.doi.org/10.1186/1742-4682-9-27

[12] Pokorný, J., Hašek, J. and Jelínek, F. (2005) Electromagnetic Field of Microtubules: Effects on Transfer of Mass Particles and Electrons. Journal of Biological Physics, 31, 501-514. http://dx.doi.org/10.1007/s10867-005-1286-1

[13] Moritz, M., Braunfeld, M.B., Guénebaut, V., Heuser, J. and Agard, D.A. (2000) Structure of the $\gamma$-Tubulin Ring Complex: A Template for Microtubule Nucleation. Nature Cell Biology, 2, 365-370. http://dx.doi.org/10.1038/35014058

[14] Schafer, P.W. (1969) Centrioles of a Human Cancer: Intercellular Order and Intracellular Disorder. Science, 164, 1300-1303. http://dx.doi.org/10.1126/science.164.3885.1300

[15] Schafer, P.W. and Chandler, J.A. (1970) Electron Probe X-Ray Microanalysis of a Normal Centriole. Science, 170, 1204-1205. http://dx.doi.org/10.1126/science.170.3963.1204

[16] Schafer, P.W. (1972) Centrioles: Intercellular Order in Normal and Malignant Cells. The Journal of Thoracic and Cardiovascular Surgery, 63, 472-477.

[17] Mennella, V., Agard, D.A., Huang, B. and Pelletier, L. (2014) Amorphous No More: Subdiffraction View of the Pericentriolar Material Architecture. Trends in Cell Biology, 24, 188-197. http://dx.doi.org/10.1016/j.tcb.2013.10.001

[18] Pokorný, J., Hasek, J., Vanis, J. and Jelínek, F. (2008) Biophysical Aspects of Cancer-Eletromagnetic Mechanism. Indian Journal of Experimental Biology, 46, 310-321. 
[19] Pokorný, J., Pokorný, J. and Kobilková, J. (2013) Postulates on Electromagnetic Activity in Biological Systems and Cancer. Integrative Biology, 5, 1439-1446.

http://dx.doi.org/10.1039/c3ib40166a

[20] Azimzadeh, J. and Marshall, W.F. (2010) Building the Centriole. Current Biology, 20, R816R825. http://dx.doi.org/10.1016/j.cub.2010.08.010

[21] Meggs, W.J. (1988) Electric Fields Determine the Spatial Organization of Microtubules and Actin Filaments. Medical Hypotheses, 26, 165-170. http://dx.doi.org/10.1016/0306-9877(88)90095-3

[22] Cifra, M., Pokorný, J., Havelka, D. and Kučera, O. (2010) Electric Field Generated by Axial Longitudinal Vibration Modes of Microtuble. Biosystems, 100, 122-131. http://dx.doi.org/10.1016/j.biosystems.2010.02.007

[23] Tsai, M.C. and Ahringer, J. (2007) Microtubules Are Involved in Anterior-Posterior Axis Formation in C. elegans Embryos. Journal of Cell Biology, 179, 397-402. http://dx.doi.org/10.1083/jcb.200708101

[24] McKean, P.G., Vaughan, S. and Gull, K. (2001) The Extended Tubulin Superfamily. Journal of Cell Science, 114, 2723-2733.

[25] Werner, M.E., Hwang, P., Huisman, F., Taborek, P., Yu, C.C. and Mitchell, B.J. (2011) Actin and Microtubules Drive Differential Aspects of Planar Cell Polarity in Multiciliated Cells. Journal of Cell Biology, 195, 19-26. http://dx.doi.org/10.1083/jcb.201106110

[26] Nigg, E.A. and Stearns, T. (2011) The Centrosome Cycle: Centriole Biogenesis, Duplication and Inherent Asymmetries. Nature Cell Biology, 13, 1154-1160.

http://dx.doi.org/10.1038/ncb2345

[27] Cifra, M., Fields, J.Z. and Farhadi, A. (2011) Electromagnetic Cellular Interactions. Progress in Biophysics and Molecular Biology, 105, 223-246. http://dx.doi.org/10.1016/j.pbiomolbio.2010.07.003

[28] Josephs, H. and Huston, R.L. (2002) Dynamics of Mechanical Systems. CRC Press, Boca Raton. http://dx.doi.org/10.1201/9781420041927

[29] Cuzick, J., Holland, R., Barth, V., et al. (1998) Electropotential Measurements as a New Diagnostic Modality for Breast Cancer. The Lancet, 352, 359-363. http://dx.doi.org/10.1016/S0140-6736(97)10002-2

[30] Zhao, M., Bai, H., Wang, E., Forrester, J.V. and McCaig, C.D. (2004) Electrical Stimulation Directly Induced Pre-Angiogenic Responses in Vascular Endothelial Cells by Signaling through YEGF Receptors. Journal of Cell Science, 117, 397-405. http://dx.doi.org/10.1242/jcs.00868

[31] McCaig, C.D., Rajnicek, A.M., Song, B. and Zhao, M. (2005) Controlling Cell Behavior Electrically: Current Views and Future Potential. Physiological Review, 85, 943-978. http://dx.doi.org/10.1152/physrev.00020.2004

[32] Binggeli, R. and Weinstein, R.C. (1986) Membrane Potentials and Sodium Channels: Hypotheses for Growth Regulation and Cancer Formation Based on Changes in Sodium Channels and Gap Junctions. Journal of Theoretical Biology, 123, 377-401. http://dx.doi.org/10.1016/S0022-5193(86)80209-0

[33] Djamgoz, M.B.A., Mycielska, M., Madeja, Z., Fraser, S.P. and Korohoda, W. (2001) Directional Movement of Rat Prostate Cancer Cells in Direct-Current Electric Field: Involvement of Voltagegated $\mathrm{Na}^{+}$Channel Activity. Journal of Cell Science, 114, 2697-2705.

[34] Pokorný, J. (2012) Physical Aspects of Biological Activity and Cancer. AIP Advances, 2, Article ID: 011207. http://dx.doi.org/10.1063/1.3699057 
[35] Hochwald, S.N. (2010) Molecular-Targeted Therapy for Cancer and Nanotechnology. In: Grobmyer, S.R. and Moudgil, B.M., Eds., Cancer Nanotechnology, Humana Press, 11-23. http://dx.doi.org/10.1007/978-1-60761-609-2 2

[36] Duensing, S. (2005) A Tentative Classification of Centrosome Abnormalities in Cancer. Cell Biology International, 29, 352-359. http://dx.doi.org/10.1016/j.cellbi.2005.03.005

[37] Schöckel, L., Möckel, M., Mayer, B., Boos, D. and Stemmann, O. (2011) Cleavage of Cohesion Rings Coordinates the Separation of Centrioles and Chromatids. Nature Cell Biology, 13, 966-972. http://dx.doi.org/10.1038/ncb2280

[38] Nigg, E.A. and Raft, J.W. (2009) Centrioles, Centrosomes, and Cilia in Health and Disease. Cell, 139, 663-678. http://dx.doi.org/10.1016/j.cell.2009.10.036

[39] Kobayashi, T. and Dynlacht, B.D. (2011) Regulating the Transition from Centriole to Basal Body. Journal of Cell Biology, 193, 435-444. http://dx.doi.org/10.1083/jcb.201101005

[40] Ganem, N.J., Godinho, S.A. and Pellman, D. (2009) A Mechanism Linking Extra Centrosomes to Chromosomal Instability. Nature, 460, 278-282. http://dx.doi.org/10.1038/nature08136

[41] Nigg, E.A. (2002) Centrosome Aberrations: Cause or Consequence of Cancer Progression? Nature Reviews Cancer, 2, 815-825. http://dx.doi.org/10.1038/nrc924

[42] Korzeniewski, N., Hohenfellner, M. and Duensing, S. (2012) CANDI Promotes PLK4-Mediated Centriole Overduplication and Is Frequently Disrupted in Prostate Cancer. Neoplasia, 14, 799-806. http://dx.doi.org/10.1593/neo.12580

[43] Nigg, E.A. (2006) Origins and Consequences of Centrosome Aberrations in Human Cancers. International Journal of Cancer, 119, 2717-2723. http://dx.doi.org/10.1002/ijc.22245

[44] Godinho, S.A., Kwon, M. and Pellman, D. (2009) Centrosomes and Cancer: How Cancer Cells Divide with Too Many Centrosomes. Cancer and Metastasis Reviews, 28, 85-98. http://dx.doi.org/10.1007/s10555-008-9163-6

[45] Sluder, G. and Nordberg, J.J. (2004) The Good, the Bad and the Ugly: The Practical Consequences of Centrosome Amplification. Current Opinion in Cell Biology, 16, 49-54. http://dx.doi.org/10.1016/j.ceb.2003.11.006

[46] Brinkley, B.R. (2001) Managing the Centrosome Numbers Game: From Chaos to Stability in Cancer Cell Division. Trends in Cell Biology, 11, 18-21. http://dx.doi.org/10.1016/S0962-8924(00)01872-9

[47] D'Assoro, A.B., Lingle, W.L. and Salisbury, J.L. (2002) Centrosome Amplification and the Development of Cancer. Oncogene, 21, 6146-6153. http://dx.doi.org/10.1038/sj.onc.1205772

[48] Tsou, M.F. and Stearns, T. (2006) Mechanism Limiting Centrosome Duplication to Once per Cell Cycle. Nature, 442, 947-951. http://dx.doi.org/10.1038/nature04985

[49] Bettencourt-Dias, M. and Glover, D.M. (2009) SnapShot: Centriole Biogenesis. Cell, 136, 188.e1-188.e2. http://dx.doi.org/10.1016/j.cell.2008.12.035

[50] Löffler, H., Fechter, A., Liu, F.Y., Poppelreuther, S. and Krämer, A. (2013) DNA DamageInduced Centrosome Amplification Occurs via Excessive Formation of Centriolar Satellites. Oncogene, 32, 2963-2972. http://dx.doi.org/10.1038/onc.2012.310

[51] Dobson, J. (2008) Remote Control of Cellular Behaviour with Magnetic Nanoparticles. Nature Nanotechnology, 3, 139-143. http://dx.doi.org/10.1038/nnano.2008.39

[52] Lingle, W.L., Barrett, S.L., Negron, V.C., D’Assoro, A.B., Boeneman, K., Liu, W., Whitehead, C.M., Reynolds, C. and Salisbury, J.L. (2002) Centrosome Amplification Drives Chromosomal Instability in Breast Tumor Development. Proceedings of the National Academy of Sciences of the United States of America, 99, 1978-1983. 
http://dx.doi.org/10.1073/pnas.032479999

[53] Rodrigues-Martins, A., Riparbelli, M., Callaini, G., Glover, D.M. and Bettencourt-Dias, M. (2008) From Centriole Biogenesis to Cellular Function: Centrioles Are Essential for Cell Division at Critical Developmental Stages. Cell Cycle, 7, 11-16. http://dx.doi.org/10.4161/cc.7.1.5226

[54] Krämer, A., Neben, K. and Ho, A.D. (2002) Centrosome Replication, Genomic Instability and Cancer. Leukemia, 16, 767-775. http://dx.doi.org/10.1038/sj.leu.2402454

[55] Vulprecht, J., David, A., Tibelius, A., Castiel, A., Konotop, G., Liu, F., Bestvater, F., Raab, M.S., Zentgraf, H., Izraeli, S. and Krämer, A. (2012) STIL Is Required for Centriole Duplication in Human Cells. Journal of Cell Science, 125, 1353-1362. http://dx.doi.org/10.1242/jcs.104109

[56] Kwon, M., Godinho, S.A., Chandhok, N.S., Ganem, N.J., Azioune, A., Thery, M. and Pellman, D. (2008) Mechanisms to Suppress Multipolar Divisions in Cancer Cells with Extra Chromosomes. Genes \& Development, 22, 2189-2203.

[57] Pihan, G.A., Wallace, J., Zhou, Y. and Doxsey, S.J. (2003) Centrosome Abnormalities and Chromosome Instability Occur Together in Pre-Invasive Carcinomas. Cancer Research, 63, 1398-1404.

[58] Holland, A.J., Lan, W., Niessen, S., Hoover, H. and Cleveland, D.W. (2010) Polo-Like Kinase 4 Kinase Activity Limits Centrosome Overduplication by Autoregulating Its Own Stability. The Journal of Cell Biology, 188, 191-198. http://dx.doi.org/10.1083/jcb.200911102

[59] Lingle, W.L. and Salisbury, J.L. (2000) The Role of the Centrosome in the Development of Malignant Tumors. Current Topics in Developmental Biology, 49, 313-339. http://dx.doi.org/10.1016/S0070-2153(99)49015-5

[60] Goepfert, T.M., Adigun, Y.E., Zhong, L., Gay, J., Medina, D. and Brinkley, W.R. (2002) Centrosome Amplification and Overexpression of Aurora A Are Early Events in Rat Mammary Carcinogenesis. Cancer Research, 62, 4115-4122.

[61] Marx, J. (2001) Do Centrosome Abnormalities Lead to Cancer? Science, 292, 426-429. http://dx.doi.org/10.1126/science.292.5516.426

[62] Marthiens, V., Rujano, M.A., Pennetier, C., Tessier, S., Paul-Gilloteaux, P. and Basto, R. (2013) Centrosome Amplification Causes Microcephaly. Nature Cell Biology, 15, 731-740. http://dx.doi.org/10.1038/ncb2746

[63] Maiato, H. and Logarinho, E. (2014) Mitotic Spindle Multipolarity without Centrosome Amplifications. Nature Cell Biology, 16, 386-394. http://dx.doi.org/10.1038/ncb2958

[64] Lingle, W.L. and Salisbury, J.L. (1999) Altered Centrosome Structure Is Associated with Abnormal Mitoses in Human Breast Tumors. American Journal of Pathology, 155, 19411951. http://dx.doi.org/10.1016/S0002-9440(10)65513-7

[65] Yang, Z., Loncarek, J., Khodjakov, A. and Rieder, C.I. (2008) Extra Centrosomes and/or Chromosomes Prolong Mitosis in Human Cells. Nature Cell Biology, 10, 748-751. http://dx.doi.org/10.1038/ncb1738

[66] Leber, B., Maier, B., Fuchs, F., Chi, J., Riffel, P., Anderhub, S., Wagner, L., Ho, A.D., Salisbury, J.L., Boutros, M. and Krämer, A. (2010) Proteins Required for Centrosome Clustering in Cancer Cells. Science Translational Medicine, 2, 33ra38. http://dx.doi.org/10.1126/scitranslmed.3000915

[67] Pihan, G.A., Purohit, A., Wallace, J., Knecht, H., Woda, B., Quesenberry, P. and Doxsey, S.J. (1998) Centrosome Defects and Genetic Instability in Malignant Tumors. Cancer Research, 58, 3974-3985. 
[68] Lingle, W.L., Lutz, W.H., Ingle, J.N., Maihle, N.J. and Salisbury, J.L. (1998) Centrosome Hypertrophy in Human Breast Tumors: Implications for Genomic Stability and Cell Polarity. Proceedings of the National Academy of Sciences of the United States of America, 95, 2950-2955. http://dx.doi.org/10.1073/pnas.95.6.2950

[69] Bornens, M. (2008) Organelle Positioning and Cell Polarity. Nature Reviews Molecular Cell Biology, 9, 874-886. http://dx.doi.org/10.1038/nrm2524

[70] Fukasawa, K. (2007) Oncogenes and Tumour Suppressors Take on Centrosomes. Nature Reviews Cancer, 7, 911-924. http://dx.doi.org/10.1038/nrc2249

[71] Marthiens, V., Piel, M. and Basto, R. (2012) Never Tear Us Apart-The Importance of Centrosome Clustering. Journal of Cell Science, 125, 3281-3292. http://dx.doi.org/10.1242/jcs.094797

[72] Kanno, S., Oda, N., Abe, M., Saito, S., Hori, K., Handa, Y., Tabayashi, K. and Sato, Y. (1999) Establishment of a Simple and Practical Procedure Applicable to Therapeutic Angiogenesis. Circulation, 99, 2682-2687. http://dx.doi.org/10.1161/01.CIR.99.20.2682

[73] Hol, W.G. (1985) The Role of the Alpha-Helix Dipole in Protein Function and Structure. Progress in Biophysics and Molecular Biology, 45, 149-195. http://dx.doi.org/10.1016/0079-6107(85)90001-X

[74] Sataric, M.V., Tuszynski, J.A. and Zakula, R.B. (1993) Kinklike Excitations as an EnergyTransfer Mechanism in Microtubules. Physical Review E, 48, 589-597. http://dx.doi.org/10.1103/PhysRevE.48.589

[75] Brown, J.A. and Tuszynski, J.A. (1999) A Review of the Ferroelectric Model of Microtubules. Ferroelectrics, 220, 141-155. http://dx.doi.org/10.1080/00150199908216213

[76] Mycielska, M.E. and Djamgoz, M.B. (2004) Cellular Mechanisms of Direct-Current Electric Field Effects: Galvanotaxis and Metastatic Disease. Journal of Cell Science, 177, 1631-1639. http://dx.doi.org/10.1242/jcs.01125

[77] Stracke, R., Bohm, K.J., Wullweber, L., Taszynski, J. and Unger, E. (2002) Analysis of the Migration Behavior of Single Microtubules in Electric Fields. Biochemical and Biophysical Research Communications, 293, 602-609. http://dx.doi.org/10.1016/S0006-291X(02)00251-6

[78] Pokorný, J. (2003) Viscous Effects on Polar Vibrations in Microtubules. Electromagnetic Biology and Medicine, 22, 15-29. http://dx.doi.org/10.1081/JBC-120020349

[79] Havelka, D. and Cifra, M. (2009) Calculation of the Electromagnetic Field around a Microtubule. Acta Polytechnica, 49, 58-63.

[80] Böhm, K.J., Mavromatos, N.E., Michette, A., Stracle. R. and Unger, E. (2005) Movement and Alignment of Microtubules in Electric Fields and Electric-Dipole-Moment Estimates. Electromagnetic Biology and Medicine, 24, 319-330. http://dx.doi.org/10.1080/15368370500380010

[81] Pokorný, J. (2001) Endogenous Electromagnetic Forces in Living Cells: Implications for Transfer of Reaction Components. Electro- and Magnetobiology, 20, 59-73. http://dx.doi.org/10.1081/JBC-100103160

[82] Cifra, M., Havelka, D. and Kucera, O. (2010) Electric Oscillations Generated by Collective Vibration Modes of Microtubules. In: Kinnamen, M. and Myllyla, R., Eds., Laser Applications in Life Sciences, Proceedings of SPIE, Vol. 7376, 73760N. http://dx.doi.org/10.1117/12.870929

[83] Pokorný, J., Vedruccio, C., Cifra, M. and Kučera, O. (2011) Cancer Physics: Diagnosis Based on Damped Cellular Elastoelectrical Vibrations in Microtubules. European Biophysics Journal, 40, 747-759. http://dx.doi.org/10.1007/s00249-011-0688-1 
[84] Mannix, R.J., Kumar, S., Cassiola, F., Montoya-Zavala, M., Feinstein, E, Prentiss, M. and Ingber, D.E. (2008) Nanomagnetic Actuation of Receptor-Mediated Signal Transduction. Nature Nanotechnology, 3, 36-40. http://dx.doi.org/10.1038/nnano.2007.418

[85] Klebba, J.E., Galletta, B.J., Nye, J., Plevock, K.M., Buster, D.W., Hollingsworth, N.A., Slep, K.C., Rusan, N.M. and Rogers, G.C. (2015) Two Polo-Like Kinase 4 Binding Domains in Asterless Perform Distinct Roles in Regulating Kinase Stability. Journal of Cell Biology, 208, 401-414. http://dx.doi.org/10.1083/jcb.201410105

\section{Submit or recommend next manuscript to SCIRP and we will provide best service for you:}

Accepting pre-submission inquiries through Email, Facebook, LinkedIn, Twitter, etc. A wide selection of journals (inclusive of 9 subjects, more than 200 journals)

Providing 24-hour high-quality service

User-friendly online submission system

Fair and swift peer-review system

Efficient typesetting and proofreading procedure

Display of the result of downloads and visits, as well as the number of cited articles Maximum dissemination of your research work

Submit your manuscript at: http://papersubmission.scirp.org/ 